\title{
A method to estimate the demand for freight transport in absence of historical data. A case study of the Oder Waterway
}

\author{
Ludmiła Filina-Dawidowicz ${ }^{1, *}$, Izabela Kotowska $^{2}$, Marta Mańkowska $^{3}$, and \\ Michat Pluciński ${ }^{3}$ \\ ${ }^{1}$ West Pomeranian University of Technology, Faculty of Maritime Technology and Transport, \\ 41 Piastów Ave., 71065 Szczecin, Poland \\ ${ }^{2}$ Maritime University of Szczecin, Faculty of Engineering and Economics of Transport, 11 Henryka \\ Pobożnego St., 70507 Szczecin, Poland \\ ${ }^{3}$ University of Szczecin, Faculty of Management and Economics of Services, 8 Cukrowa St., \\ 71004 Szczecin, Poland
}

\begin{abstract}
The aim of the research described in this article is to work out a method to estimate the demand for freight transport in a situation when no historical data are available, thus rendering it impossible to apply methods based on time series data. The method presented in this article was developed and verified on the basis of an analysis of potential inland shipping operations on the Oder Waterway to/from the seaports in Szczecin and Świnoujście, assuming that the waterway has been upgraded to navigability class III. The analysis was predicated on a demand survey performed among cargo shippers. The obtained research results made it possible to specify the advantages and drawbacks of forecasting based on qualitative methods, and to identify the factors which significantly reduce the reliability of freight transport forecasts.
\end{abstract}

\section{Introduction}

Studies of demand for transport services are of key importance in the theory of transport economics. They are used to initiate the process of forecasting the development of a transport system, and they constitute the basis for decision-making with regard to planning any linear and point infrastructure. Reliable determination of transport needs is necessary to rationalise transport processes in compliance with the idea of sustained development [e.g. 1, 2, 3]. The answer to these challenges is promoting the modal shift from road transport to inland shipping [e.g. 4, 5, 6, 7, 8, 9].

Recently, in European countries more and more emphasis is put on inland shipping development. This situation is also observed in Poland. To that end, the major waterways in Poland are to be upgraded to a navigation class of at least IV [10]. In terms of investment measures, the highest priority has been assigned to the Oder Waterway (OW). Due the longstanding negligence resulting in a very bad technical condition of the waterway, the estimated

\footnotetext{
*Corresponding author: ludmila.filina@zut.edu.pl
} 
cost of investment in the OW amounts to: PLN 2.9 billion until 2020, and PLN 27.8 billion from 2021 to 2030 [11].

The considerable capital intensity of the planned investment measures should be justified by anticipated freight transport volumes, the cargo structure, and the directional structure of freight transport on the OW after it's been made fully navigable. In a situation when input data are available from official sources (e.g. EUROSTAT), cargo flow modelling and transport volume estimation is usually done by means of quantitative methods. However, application of a methodology predicated on time series for the purpose of estimating the demand for inland shipping in Poland is constrained and unreasonable mainly because of the lack of historical data. Apart from the sporadic local use of inland waterways, currently inland shipping is not used in serving cargo flows in Poland.

The aim of the studies described in this article is to work out an optimal method to estimate the demand for inland shipping, taking into account the constraints related to its current condition (the lack of historical data) and the plans of upgrading the major inland waterways in the future. The method described in this article was developed and verified on the basis of an analysis of potential inland shipping operations on the Oder Waterway to/from the seaports, assuming that the waterway has been upgraded to navigability class III. The obtained research results also made it possible to determine the advantages and drawbacks of forecasting based on qualitative methods and to identify the factors which significantly reduce the reliability of freight transport forecasts. Although the article focuses specifically on the case study of the OW and Szczecin and Świnoujście sea ports, the proposed method could be used in other countries and in relation to other modes of transport in the absence of historical data. Thus, the research results presented in this article provide generalized conclusions.

\section{Literature overview}

According to Rolbiecki [12], the fundamental issue in estimating the demand for transport services is to identify any transformations taking place in the transport system (endogenous factors) and in its environment (exogenous factors). The intra-transport factors such as e.g. changes in the transport infrastructure availability are particularly important in estimating the demand for transport services with regard to the individual transport modes, also in the case of assumed modal shifts of the demand to alternative modes of transport.

Reliability of transport demand estimates is also affected by the choice of research methods and by the source data selection. Source data may be obtained from secondary and primary sources. Primary data provide more precise information on the demand structure, however, it may be difficult and time-consuming to obtain them. Also, as opposed to secondary data sourced from official statistics databases, primary data faster become out-ofdate.

A large portion of research studies in the area of forecasting and modelling the demand for transport pertains to passenger traffic, including the one in conurbations [e.g. 13, 14, 15, $16,17,18,19]$. Freight transport issues are addressed to a lesser extent [e.g. 20, 21, 22, 23, $24,25]$, which is connected with the lesser availability of comparable source data. The basic groups of methods applied to estimate the demand for transport include the methods predicated on quantitative and qualitative techniques $[21,26,27,28,29,30]$. The quantitative methods include the linear trend extrapolation method (examining the direction and rate of changes), the comparative (ratio) analysis method, and econometric modelling [12]. The two former methods are traditional methods based on the time function and an assumption that in the future the demand for transport will be showing a trend that is similar to the one observed so far, and the factors determining this trend will not change. The econometric modelling 
methods make it possible to identify a correlation between one or more analysed phenomena and other factors, and enable forecasting their future behaviours.

The qualitative methods, in turn, consist in observation of facts and obtaining the knowledge which is the basis for formulation of theorems and generalised regularities [12, 31]. Within this group, we distinguish between the demoscopic and expert methods. The demoscopic methods consist in obtaining, directly from cargo shippers, data regarding the volume and structure of their transport needs, and also information on the subjective motifs of transport users' preferences, e.g. with respect to transport time and costs. When researchers apply this method, they select a group of major cargo shippers who generate the biggest transport volumes and who are based within a specified area. The expert methods, in turn, consist in a logical analysis of a problem by a team of experts having appropriate expertise, skills and experience.

Estimation of transport demand by means of the specified groups of methods has its advantages and drawbacks [e.g. 20, 32, 33, 31, 34, 22]. The main advantage of the quantitative methods is their objectivity, whereas the drawbacks include insufficient identification of changes of the qualitative nature in the demand structure, and of changes taking place in the external environment. Forecasts based on the quantitative methods are short-term by nature $[27,35]$. The methods are useless if there are no historical data on transport. The weaknesses of the quantitative methods are at the same time the strengths of the qualitative methods. The qualitative methods enable identification of changes in cargo shippers' decision-making processes, and consequently more precise estimation of the demand.

Estimation of the demand for inland shipping in Poland requires an innovative methodological approach based mainly on the qualitative methods. This is due to the fact that this mode of transport has so far been used in cargo operations only to a negligible extent, and there are no input data that could be applied to make forecasts by means of the quantitative methods.

\section{Methodology}

The methodology applied in developing the forecast of inland shipping volumes (on the Oder Waterway) was predicated on the assumption of moving some of the cargoes from the Oder corridor (road and rail haulage) to inland shipping to/from the seaports of Szczecin and Świnoujście. Four stages were involved in working out the methodology.

The first stage pertained to evaluation of the hinterland potential and the intermodal shift possibilities. To that end, we analysed the trading volume and structure of the businesses located in the areas that gravitate to inland shipping. The area covered by the study was limited to the areas located no further than $50 \mathrm{~km}$ from the Oder Waterway. The study included selected districts (poviats) in five provinces (voivodeships): Lubuskie, Wielkopolskie, Dolnośląskie, Opolskie, and Śląskie. The presented analysis of the hinterland potential was performed on the basis of the input data obtained from the Analytical Centre of the Customs Administration (ACCA).

The second stage covered the demand research studies which were performed twice, i.e. in 2015 and 2017. The studies run in 2015 applied the ACCA data for 2014, while the studies of 2017 used the ACCA data for 2016. At this stage, the techniques of demoscopic and expert methods were applied. The ACCA data helped identify the major exporters and importers who made use of maritime transport and were based within the area of the districts covered by the study. The study involved businesses which generated annual import/export volumes of more than 10 thou tonnes (identification as per the data for 2014 and 2016). Both industrial plants and trading companies were found among the major exporters/ importers located within the studied area. Expert interviews were held with a selected group of entities: 48 
entities in 2015, and 42 entities in 2017. The interviews were conducted in the course of personal meetings, video conferences and conversations on the telephone. In those interviews, the interviewees representing the entities were usually directors/ managers of the units responsible for delivery/ distribution logistics. In the course of the interviews, the shippers were asked: In case the whole inland waterway has been upgraded to navigability class III, and the navigable season is guaranteed, would that incline you to shift some of the transported cargoes to inland shipping? When a cargo shipper showed interest in such a modal shift, subsequent questions regarded the expected level of the price advantage of inland shipping (water-land chain) in relation to the rail and road haulage, and the scale (volume) of the possible modal shift to inland shipping (water-land chain).

In the course of the interviews, the entities declared that they were willing to shift some cargoes (which presently were carried by other transport modes) to inland shipping or to a land-water chain.

Due to the fact that the declarations obtained in 2017 involved considerable changes in the transport directions declared by the entities' representatives in relation to 2015 , the transport directions were verified, mainly in terms of their durability.

The third stage was devoted to the comparative analysis of costs of transport over selected routes to/from the seaports of Szczecin and Świnoujście, involving various transport modes: road and rail haulage and inland shipping, or - in the case any given entity did not have a direct access to a waterway - a water-land chain. The analysis made it possible to evaluate the competitive position of inland shipping in relation to other transport modes and to estimate transport forecasts.

Finally (4th stage), the volume and structure of intersectoral shifts and inter-corridor shifts in expected demand were estimated.

The research material obtained as a result of the previous stages provided us with a detailed knowledge about:

- current level of transport volume, type of cargo and route of transport of each of the shippers

- the threshold value (\%) of transport costs reduction which induces the shippers to make a decision on the modal shift

- the cost of transport of different types of cargo on individual routes

- percentage of cargo shifted to inland shipping in case the OW operational parameters are improved (ensuring safety and reliability of transport)

- investment plans resulting in changes in the volume of transport and in the organisation of supply chains.

Bearing in mind the above, the potential annual demand for transport on the OW was estimated. The forecast only includes those cargo groups for which the cost simulation has shown that after the waterway modernization the following condition will be met:

$$
T C_{i s}<\left(1-t_{i}\right) \cdot T C_{r / r t}
$$

$T C_{i s}-$ transport costs of cargo in inland shipping after the OW modernisation [PLN] $T C_{r / r t}-$ costs of road/rail transport [PLN]

$t_{i}$-value of transport costs reduction for shippers to make a decision on modal shift [\%].

The potential volume of transport $\left[V O L_{i s}\right]$ was estimated based on the formula:

$$
V O L_{i s}=\sum_{i=1}^{m}\left(V O L_{i} \cdot p_{i}+F V O L_{i}\right)
$$


$V O L_{i}$ - annual transport of cargo to/from the seaports by shipper $i$ (by road and rail transport) $[\mathrm{t}]$

$p_{i}-$ declared percentage of cargo volume shifted to inland shipping after the modernisation [\%]

$\mathrm{FVOL}_{i}$ - future potential of cargo individually declared by shipper $i$ to inland shipping,

[t]

$m$ - number of interviewees.

\section{Results}

\subsection{The forecast of demand for inland shipping to/from Szczecin and Świnoujście seaports - empirical studies}

The selected entities were located within the Oder Waterway belt covered by the study, in the provinces (voivodeships): Śląskie, Opolskie, Dolnośląskie, Wielkopolskie, and Lubuskie, and generated international transport volumes at the level of ca. 70 million tonnes per year, while in 2016 they were ca. 10\% higher than in 2014. The majority of the international cargoes were carried by rail and by road. Only a small percentage of the cargoes - ca. 10 million tonnes - was carried by sea (Table 1 ).

Over the years 2014-2016, the volume of maritime transport increased by mere $6 \%$. The increase was noticeable in all cargo groups apart from chemical products, machinery and devices.

The biggest cargo group was mineral products, i.e. coal, coke, iron ore, aggregate, this group also included liquid bulk cargoes, i.e. fuels. The transport volume of these cargoes was at the level of 7-7.5 million tonnes, out of which 6.5 million tonnes were destined to/from shippers from the Śląskie province. This cargo group is characterised by a low unit value, which makes it particularly suitable for inland shipping.

The second biggest cargo group in terms of volume was base metals and articles thereof. Nearly 1 million tonnes of these were transported via the seaports, mainly as imports. The cargoes were transported mainly to/ from the voivodeships: Dolnośląskie, Śląskie, and Opolskie.

The third major cargo group was chemical products, including chemical fertilisers. Over the years 2014-2016, a drop of over 30\% was observed in the transport volume for this group via the seaports. The provinces of Dolnośląskie and Opolskie had the biggest share in chemical products transport volumes.

As for grain and feed, ACCA statistics do not reflect the actual cargo flows, since what they show is the trade of companies registered in the studied area, not the actual production. In 2016, the maritime trade of agricultural products from the studied area amounted to less than 50 thou tonnes. The other cargoes in this group were carried mainly by road to/from European destinations, which is due to the considerable availability of this transport mode and the considerable market fragmentation.

Other cargo constituted general cargo. Some of the cargo, e.g. cellulose, wood, and project cargo, largely lend themselves to inland shipping in both technical and economic terms.

Nearly 0.3 million tonnes of cellulose (classified as wood pulp, paper and cardboard) were transported annually, mainly to Kostrzyn-on-Oder where paper mills are located.

Inland shipping lends itself to transporting project cargoes, as these usually involve heavy and oversized items, in particular machines and equipment. Ca. 0.2 million tonnes of such cargoes were transported per year. 
The biggest increase in transhipment volumes in the years covered by the study was observed in other cargo group. This group comprised general cargo, i.e. textiles, foodstuffs, plastics, various finished goods, which are not suitable for inland shipping, unless it is containerised general cargo (in the case of navigability class III, container transport is constrained).

Table 1. Trade by sea in the analysed OW hinterland (tonnes, 2014 and 2016),

(Source: own work based on ACCA data)

\begin{tabular}{|c|c|c|c|c|c|c|c|}
\hline Products & Year & Śląskie & $\begin{array}{c}\text { Opol- } \\
\text { skie }\end{array}$ & $\begin{array}{l}\text { Dolno- } \\
\text { śląskie }\end{array}$ & $\begin{array}{l}\text { Wielko- } \\
\text { polskie }\end{array}$ & $\begin{array}{c}\text { Lubu- } \\
\text { skie }\end{array}$ & Total \\
\hline \multirow{2}{*}{$\begin{array}{l}\text { Mineral } \\
\text { products }\end{array}$} & 2014 & 6547195 & 314835 & 242663 & 1862 & 33013 & 7139568 \\
\hline & 2016 & 6773674 & 416465 & 283058 & 2454 & 43139 & 7518790 \\
\hline \multirow{2}{*}{$\begin{array}{l}\text { Base metals } \\
\text { and articles } \\
\text { thereof }\end{array}$} & 2014 & 239069 & 168599 & 246400 & 146329 & 11108 & 811505 \\
\hline & 2016 & 277415 & 212515 & 315888 & 128455 & 12993 & 947266 \\
\hline \multirow{2}{*}{$\begin{array}{l}\text { Products of } \\
\text { the chemical } \\
\text { industry }\end{array}$} & 2014 & 48934 & 115384 & 299027 & 146 & 2412 & 465903 \\
\hline & 2016 & 51079 & 109259 & 155470 & 2364 & 1366 & 319538 \\
\hline \multirow{2}{*}{$\begin{array}{l}\text { Vegetable } \\
\text { products }\end{array}$} & 2014 & 12637 & 539 & 11932 & 949 & 458 & 26515 \\
\hline & 2016 & 11556 & 1483 & 22132 & 8996 & 260 & 44427 \\
\hline \multirow{2}{*}{$\begin{array}{l}\text { Machinery } \\
\text { and } \\
\text { mechanical } \\
\text { appliances, } \\
\text { electrical } \\
\text { equipment }\end{array}$} & 2014 & 106300 & 7733 & 91373 & 7439 & 21850 & 234695 \\
\hline & 2016 & 85591 & 7788 & 85758 & 7001 & 17923 & 204061 \\
\hline \multirow{2}{*}{$\begin{array}{l}\text { Wood pulp, } \\
\text { paper and } \\
\text { paperboard } \\
\text { and articles } \\
\text { thereof }\end{array}$} & 2014 & 5025 & 137 & 5992 & 9611 & 236570 & 257335 \\
\hline & 2016 & 8157 & 250 & 8457 & 19879 & 228582 & 265325 \\
\hline \multirow{2}{*}{$\begin{array}{l}\text { Wood and } \\
\text { articles of } \\
\text { wood }\end{array}$} & 2014 & 13018 & 34323 & 2029 & 673 & 1614 & 51657 \\
\hline & 2016 & 7896 & 62638 & 1989 & 4718 & 930 & 78171 \\
\hline \multirow{2}{*}{ Other cargo } & 2014 & 280307 & 52474 & 163586 & 91010 & 81557 & 668934 \\
\hline & 2016 & 306897 & 71346 & 187146 & 155658 & 145741 & 866788 \\
\hline \multirow{2}{*}{ Total } & 2014 & 7252485 & 694024 & 1063002 & 258019 & 388582 & 9656112 \\
\hline & 2016 & 7522265 & 881745 & 1059896 & 329525 & 450933 & 10244364 \\
\hline
\end{tabular}

The analysis presented in Table 1 shows that the cargo potential of a given region, which may be shifted to inland shipping, has actually not changed in the two analysed years. This would mean that simple forecasts based on time series and involving data of 2014 and 2016 should not differ significantly. Unfortunately, forecasts predicated on historical data without accounting for additional conditions will be considerably biased.

In fact, there are many economic and political factors which are decisive for the transport volume that may be shifted to inland shipping, and they are not reflected in statistics or forecasts predicated on time series. This is proved by the forecasts regarding inland shipping to/from the seaports of Szczecin and Świnoujście, developed on the basis of direct interviews (Table 2). 
Table 2. Comparison of estimated demands for inland shipping to/from the Szczecin - Świnoujście port complex after the OW has been upgraded to at least class III, based on interviews of 2015 and 2017 (Source: own work)

\begin{tabular}{|l|c|c|}
\hline \multicolumn{1}{|c|}{ Cargo group } & $\mathbf{2 0 1 5}$ & $\mathbf{2 0 1 7}$ \\
\hline Solid mineral products & 8.00 & 2.85 \\
\hline Base metals and articles & 0.40 & 0.10 \\
\hline Chemical products & 0.05 & 0.30 \\
\hline Cellulose & 0.10 & 0.10 \\
\hline Diesel oil & 0.60 & 0.50 \\
\hline Timber & 0.20 & 0.20 \\
\hline Stone & 0.01 & 0.01 \\
\hline Total & 9.36 & 4.06 \\
\hline
\end{tabular}

The demand forecasts prepared on the basis of interviews conducted in 2015 and 2017 differ considerably. In 2017, it was estimated that the transport volume at the level of 4 million tonnes, whereas in 2015 the amount exceeded 9 million tonnes. The biggest change was observed in the case of the transport volume forecast for solid mineral products: it fell from 8.0 million tonnes to 2.85 million tonnes (mainly coal). This is the largest and the most important cargo group in terms of a possible shift to inland shipping. Moreover, a significant increase in forecast volumes was seen in the chemical products group: from 50 thou tonnes to 300 thou tonnes, whereas there was a drop in the base metals and articles thereof group. The differences in the transport volumes forecasts can be attributed to two significant premises: the changes in the economic and political environment.

\subsection{The factors affecting the changes in the estimated volume and structure of the demand}

\subsubsection{The factors deriving from the changes in the economic environment}

In the study conducted in 2015, the most important maritime exporter of Polish coal generated transport volumes of 5 million tonnes via Polish seaports. This entity was also very much interested in the possibility of an intermodal shift to inland shipping on the Oder Waterway, and an inter-corridor shift (e.g. from the Trójmiasto ports corridor to the Oder Waterway), even if the savings on the total transport costs were less than $10 \%$ in relation to the level before the time of the study. At that time (end of March 2015), 8.2 million tonnes of coal had been accumulated on coal mine dump sites in Poland, and a similar amount could be found on storage sites of Polish coal-fired power stations. It was the time when the total coal production in Poland was at the level of 70 million tonnes per year, and coal imports amounted to ca. 10 million tonnes per year. This situation made the power coal mining and trading companies search for foreign - also overseas - sales markets.

2017 saw a change in the situation in the Polish coal mining industry. As a result of the lack of new investments in coal mines and the process of phasing out the non-profitable mines or their parts, there was a fall in coal supply. The mines transferred or planned to be transferred to the Mine Restructuring Company accounted for extraction of ca. 10-12 million tonnes of coal per year. At the same time, there was a growing demand for Polish coal on the neighbouring markets, e.g. in the Czech Republic and in Germany. The combined impact of the above listed factors led to the practically total extinction of maritime exports of Polish coal in 2017. What is more, there are no grounds to expect maritime exports to revive (and thus give rise to barge transport of coal to seaports) in the years to come. 
The extinction of overseas exports of Polish coal has also led to a significant decrease in the railway transport rates. Compared to 2015, the 2017 rates for rail haulage from the south of Poland to the seaports dropped by $1 / 4$, in some cases even by $1 / 3$. This means decreased cost competitiveness of inland shipping with regard to this cargo group.

A new category among cargoes declared in 2017 for shifting to inland shipping was coal imports. The shipper of this cargo obtained a consent from the Polish government for such imports in the second half of 2017. First consignments of the cargo were used to make mixes with Polish coal and finally they ended up on the markets of the Czech Republic, Slovakia, Hungary, Austria and Germany. In the context of the shrinking supply of Polish coal, subsequent consignments of imported coal will possibly be delivered to domestic recipients. It is hard to estimate the scale of this import in terms of the potential direction of deliveries. The closest coal supply market is Russia, with which Poland has been unsuccessfully negotiating a reduction in the natural gas prices. In view of this fact, majority of the entities covered by the study did not provide official declarations regarding the volume of imports possible in the years to come, which could be shifted to inland shipping.

Analogously to the study of 2015, also in 2017 none of the entities from the leading group in the metallurgical industry declared an intention to shift other mineral cargoes (transported in the Oder corridor) to inland shipping. Similarly, in the case of imported coal and iron ore cargoes as well as coke exports, nobody declared shifting them, even partially, to inland shipping. However, a new argument came up that is unfavourable to the modal shift, i.e. the restructuring that is under way in the production plants in the metallurgical industry. This results in reluctance to incur any additional costs that are necessary at the initial stages of introducing new transport and logistics solutions.

Another factor related to the market changes observed in the years 2015-2017 was connected with the continuing process of the so-called shift in the directional structure of Polish coke trading. Polish coke plants have been increasing the extent of their products sales on the European markets. The decrease in the maritime exports of coke is definitely a factor that discourages anybody from making decisions on changing the mode of transport to seaports.

\subsubsection{The factors deriving from the changes in the political environment}

In the interviews conducted in 2015 with representatives of power plants located within the Oder Waterway region, the respondents pointed out to the economic account as the only basis for decision-making with regard to any changes in raw material supply sources and transport solutions. Knowing the situation on the international coal markets, the outcomes of the discussions inclined us to outline a realistic scenario for taking over by inland shipping ca. $50 \%$ of coal deliveries volume destined to the power plants located in the Oder Waterway belt (i.e. ca. 4 million tonnes via seaports after 2019).

In the second half of 2015, a parliamentary election was held in Poland. The declarations made by the new Polish government strongly emphasised making use of Polish coal, and even creating a permanent bond between mines and power generation companies. Thus specified policy of the new government with regard to the mining industry had a decisive effect on the declarations made by representatives of the same power plants during the survey of 2017. The significant impact of this factor is due to the fact that the State Treasury is the majority shareholder in those entities. The political factor has obviously had an impact on increased interest of the energy sector in the possibilities of diversifying the modes of transport to be used in deliveries of Polish coal to individual power plants. In particular this regards replacement of a part of rail deliveries with rail-barge chains, without deliveries via seaports. The declarations obtained in 2017 from representatives of the power plants in question were finally adjusted to result in a system of barge deliveries in mixed directions, 
i.e. 1.5 million tonnes - barge deliveries of coal via the seaports of Szczecin/Świnoujście and 1.5 million tonnes of coal deliveries from Polish mines.

Another issue is the discrepancy in the declared volume of raw material needed for the functioning of Opole power plant beyond 2019. Currently, there are four power units operating in Opole, which use ca. 3 million tonnes of coal per year. After 2019, two new power units numbered 5 and 6 will be commissioned, and their demand for coal will amount to 4.1 million tonnes per year, which adds up to more than 7 million tonnes of coal per year. However, the commissioning of the new power units will be connected with limited operation of the old power units. Still, there is no unambiguous declaration regarding the extent of this limitation. The 2015 survey forecast that the total coal consumption of Opole power plant after 2019 would be ca. 6 million tonnes. The 2017 survey indicated the level of 5 million tonnes. Any doubts and discrepancies regarding the coal consumption level are connected mainly with the planned increase in the prices of $\mathrm{CO}_{2}$ emissions allowances. For power plants, an increase in the prices will have an adverse effect on the profitability of power generation from coal, and a positive effect on the profitability of energy produced from natural gas and RES, which consequently will have an impact on further investment policies.

The political factors also influenced the changes in the volume and structure of rolled steel supplied to Poland. The main direction of maritime imports of this semi-product to the production plants based in the Oder belt and covered by the study was Russia. In the second half of 2016, the European Commission imposed an anti-dumping duty for cold rolled steel imported from Russia. Also, an analogous regulation is being considered with regard to hot rolled steel. As a result of the change in the trade policy of the European Union, importers of rolled steel were forced to search for new supply markets.

The presented economic and political factors have had a significant effect on inland shipping forecasts made for the Oder Waterway in view of its upgrading to navigability class III. Inland shipping in class III waterways is predisposed to full ship-load transport, particularly bulk cargo. In the Order Waterway corridor, the cargo that has the greatest transport potential is coal, while the major producers and consumers of coal are companies in which the State Treasury has a holding.

\subsubsection{Factors resulting from changes in the group of entities involved in the study}

Estimation of the transport volumes was also affected by changes that took place over the years 2015-2017 within the structure of the group of entities involved in the study. The major changes consiserated in the research included:

- Change in the research sample. The survey involved the entities which generated the biggest cargo volumes in maritime trading. The threshold was determined at the level of 10 thou tonnes of cargo transported to/from seaports. Some of the entities that met the criterion in 2015 no longer met it in 2017, and vice versa. Also, the 2017 survey featured new cargo shippers that were absent from the study of 2015.

- Changes taking place in the ownership structure of the entities involved in the study. The representative of a company from the mineral products sector, which in 2015 operated within a major industrial group, but in 2017 was a self-standing entity, had a different view regarding the plausibility of shifting some of their cargoes to inland shipping, compared to their opinion declared in 2015.

- Changes in the respondent group. Expert interviews are characterised by subjectivity of received responses. Personnel changes in the surveyed entities led to obtaining different responses regarding the scale of any possible intermodal shift in 2017 , in relation to the answers received in 2015.

- Changes with regard to reasons for undertaking the research. The declarations made by cargo shippers differed depending on whether the survey was conducted for merely 
orientation purposes or in connection with implementation of concrete infrastructural investment projects. In 2015, at the beginning of each interview it was stressed that the survey was not connected with financing any investment projects, and the respondents tended to think that restoring the navigability of inland waterways in Poland was rather unlikely. In 2017, interviews were started with communicating that the data were being gathered in connection with implementation of investments contributing to upgrading the Malczyce Widuchowa section of the Oder Waterway to class III. In 2017, the respondents were aware of the governmental plans to restore the navigability of major Polish rivers. The fact of referring to the concrete infrastructural projects co-financed by the EU inclined some of the respondents to formulate their views in a more balanced (reserved) manner compared to the situation in 2015. The interviewees paid more attention to the factors that do not favour a modal shift of some cargoes to inland shipping.

\section{Conclusions}

The developed and applied qualitative method of forecasting the volume of inland shipping to/from seaports after upgrading the technical parameters of the waterways makes it possible to precisely specify the volume and structure of cargo flows in the future. The method takes into account many external factors, including those economic and political, which are absent from forecasts predicated on time series. The obtained results of the research conducted using the developed method may be the basis for making rational decisions on planning an extension of a transport network. Application of the method is reasonable particularly in a situation when there are no historical data on transport volumes, as in the case of developing a transport mode that so far has been practically non-existent, e.g. inland shipping in Poland.

However, the discussed method also has its drawbacks. The conducted research has proved that changes in the economic and political environment as well as changes in the structure of the research group have a significant effect on the volume and structure of the forecast transport. Moreover, the effect is visible in a relatively short time. This was proved by the significant discrepancies between the volume of intermodal shifts of demand declared by cargo shippers in 2015 and 2017, respectively. The greater the impact of those factors on the demand volume, the greater importance of the cargo group in the estimated demand structure. In the analysed case study, this was exemplified by the considerable decrease in the volume of maritime trading of coal via seaports.

The conducted research study has also proved that the purpose of the survey affects the decision-making process of the business entities with regard to shifting their cargoes to alternative modes of transport. Linking the research results to implementation of a concrete investment project leads to a more reserved approach taken by cargo shippers to declarations made with regard to intermodal shifts of the demand.

Regardless of the indicated limitations and drawbacks of the developed method to estimate the demand for freight transport, it constitutes the best solution in case there are no historical data to rely on. The listed factors that affect the estimated results are to a large extent dependent on the "human factor". Therefore, application of this method requires verification of the obtained results in terms of durability of individual cargo flows and will direct our future research. Expert verification of the research results will make it possible to eliminate the risk of being outdated and will have a positive effect on the reliability of estimated volumes and structure of transport.

This research outcome has been achieved under the research projects MUS 8/S/IZT/2017 and US 5032500-230 675 financed from a subsidy of the Ministry of Science and Higher Education for statutory activities. 


\section{References}

1. R. A. Daziano, D. Bolduc, Incorporating pro-environmental preferences towards green automobile technologies through a Bayesian hybrid choice model. Transportmetrica A: Transp. Sc., 9, 74-106 (2013)

2. W. Y. Szeto, Guest Editorial: Special Issue on Quantitative Approaches to Environmental Sustainability in Transportation Networks. Netw. and Spat. Econ., 16, 1-8 (2016)

3. W.Y. Szeto, Y. Jiang, D.Z.W. Wang, A. Sumalee, A sustainable road network design problem with land use transportation interaction over time. Netw. and Spat. Econ., 15, 791$822(2015)$

4. S. Cheon, E. Deakin, Supply chain coordination for port sustainability: lessons for new institutional designs. Transp. Res. Rec.: J. of the Transp. Res. Board, 2166, 10-19 (2010)

5. N. S. Kim, B. Van Wee, The relative importance of factors that influence the break-even distance of intermodal freight transport systems. J. of Transp. Geogr., 19, 859-875 (2011)

6. C.-C. Chang, C.-M. Wang, Evaluating the effects of green port policy: Case study of Kaohsiung harbor in Taiwan. Transp. Res. Part D: Transport and Environment, 17, $185-$ 189 (2012)

7. J.-B. Sheu, T.-L. Hu, S.-R. Lin, The key factors of green port in sustainable development. Pakist. J. of Stat., 29, pp. 755-767 (2013)

8. S. Wang, T. Notteboom, The role of port authorities in the development of LNG bunkering facilities in North European ports. WMU J. of Marit. Aff., 14, 61-92 (2015)

9. B. Wiegmans, R. Konings, Intermodal Inland Waterway Transport: Modelling Conditions Influencing Its Cost Competitiveness. The Asian J. of Shipp. and Log., 31, 273-294 (2015)

10. M. Hann, L. Piotrowski, K. Woś, A new concept for utilising the Oder waterway in intermodal container transport. Sc. J. of Marit. Univ. in Szczecin, 47, 129-135 (2016)

11. Ministry of Maritime Economy and Inland Navigation (2016)

12. R. Rolbiecki, Badania popytu na przewozy ładunków transportem wodnym śródlądowym. Zeszyty Naukowe Uniwersytetu Gdańskiego. Ekonomika Transportu i Logistyka, 43, 41$50(2012)$

13. G. De Jong, A. Daly, M. Pieters, C. Vellay, M. Bradley, F. Hofman, A model for time of day and mode choice using error components logit. Transp. Res. Part E: Log. and Transp. Rev., 39, 245-268 (2003)

14. M. Börjesson, Joint RP-SP data in a mixed logit analysis of trip timing decisions. Transp. Res. Part E: Logistics and Transportation Review, 44, 1025-1038 (2008)

15. J. Willigers, M. de Bok, Updating and extending the disaggregate choice models in the Dutch National Model. Paper Presented at the 2009 European Transport Conference, Noordwijkerhout (2009)

16. P.R. Koster, The cost of travel time variability for air and car travellers. Doctoral Theses Economics and Business Administration (2012)

17. M. Gelhausen, P. Berster, D. Wilken, A new model of long term forecasting air passenger demand and the number of air transport movements of Germany. 2016 Atrs World Conference (2016)

18. X. Feng, M. Saito, Y. Liu, Improve urban passenger transport management by rationally forecasting traffic congestion probability. Int. J. of Prod. Res., 54, 3465-3474 (2016)

19. R. Żochowska, G. Karoń, R. Janecki, A. Sobota, Selected Aspects of the Methodology of Traffic Flows Surveys and Measurements on an Urban Agglomeration Scale with Regard to ITS Projects. In: Macioszek E., Sierpiński G. (eds) Recent Advances in Traffic 
Engineering for Transport Networks and Systems. TSTP 2017. Lecture Notes in Networks and Systems, Springer, 21, pp. 37-49 (2017)

20. W. Abdelwahab, M. Sargious, Modelling the demand for freight transport: a new approach. J. of Transp. Econ. and Pol., 26, 49-70 (1992)

21. G. De Jong, H. Gunn, W. Walker, National and international freight transport models: an overview and ideas for future development. Transp. Rev., 24, 103-124 (2004)

22. G. De Jong, M. Kouwenhoven, K. Ruijs, P van Houwe, D. Borremans, A time-period choice model for road freight transport in Flanders based on stated preference data. Transp. Res. Part E: Log. and Transp. Rev., 86, 20-31 (2016)

23. A. Valdas, R. Ruus, R. Põldaru, J. Roots, Forecasting road freight transport alternatives for sustainable regional development in Estonia. Economic Science for Rural Development Conference Proceedings, 42, 171-178 (2016)

24. M. Postan, L. Filina-Dawidowicz, Dynamic Optimization Model for Planning of Supply, Production, and Transportation of Perishable Product. In: Suchanek M. (eds) Sustainable Transport Development, Innovation and Technology. TranSopot 2016. Springer Proceedings in Business and Economics, Springer, 235-244 (2016)

25. C. W. Howe, J. L. Carroll, A. P. Hurter Jr, W.J. Leininger, S. G. Ramsey, N.L. Schwartz, E. Silberberg, R. M. Steinberg, Inland waterway transportation: studies in public and private management and investment decisions (Routledge 2016)

26. B. H. Archer, Forecasting demand: quantitative and intuitive techniques. Int. J. of Tour. Manag., 1, 5-12 (1980)

27. E. I. Vlahogianni, J. C. Golias, M. G. Karlaftis, Short-term traffic forecasting: Overview of objectives and methods. Transp. Rev., 24, 533-557 (2004)

28. J. Liu, W. Guan, A summary of traffic flow forecasting methods. J. of High. and Transp. Res. and Dev., 3, 82-85 (2004)

29. B. Atasoy, A. Glerum, R. Hurtubia, M. Bierlaire, Demand for public transport services: Integrating qualitative and quantitative methods. 10th Swiss Transport Research Conference (2010)

30. M. Patriksson, The traffic assignment problem: models and methods. Courier Dover Publications (2015)

31. D. A. Hensher \& K. J. Button (Eds.), Handbook of transport modeling (Emerald Group Publishing Limited 2007)

32. J. D. D. Ortuzar, L. G. Willumsen, Modelling transport. John Wiey \& Sons Ltd., New Delhi (2011)

33. M. Wegener, Overview of land use transport models. Handbook of transport geography and spatial systems, 127-146 (Emerald Group Publishing Limited 2004)

34. S. P. Washington, M. G. Karlaftis, F. Mannering, Statistical and econometric methods for transportation data analysis (CRC press 2010)

35. R. Chrobok, O. Kaumann, J. Wahle, M. Schreckenberg, Different methods of traffic forecast based on real data. Eur. J. of Oper. Res., 155, 558-568 (2004) 